JGR Oceans

\author{
RESEARCH ARTICLE \\ 10.1029/2020JC016185 \\ Key Points: \\ - We use an idealized \\ physical-biogeochemical and \\ buoyant plume model to test the \\ potential for meltwater-driven \\ nutrient export from fjords \\ - Modeled nutrient export is sensitive \\ to changes in subglacial discharge \\ rate and grounding line depth, \\ which impact outflow depth \\ - Factors influencing nutrient \\ residence time, including \\ shelf-forced flows, are key \\ uncertainties requiring further \\ investigation
}

Supporting Information:

- Supporting Information S1

Correspondence to:

H. Oliver,

holiver@whoi.edu

Citation:

Oliver, H., Castelao, R. M., Wang, C., \& Yager, P. L. (2020).

Meltwater-enhanced nutrient export from Greenland's glacial fjords: A sensitivity analysis. Journal of Geophysical Research: Oceans, 125, e2020JC016185. https://doi.org/ 10.1029/2020JC016185

Received 26 FEB 2020 Accepted 18 JUN 2020 Accepted article online 22 JUN 2020

(C)2020. American Geophysical Union. All Rights Reserved.

\section{Meltwater-Enhanced Nutrient Export From Greenland's Glacial Fjords: A Sensitivity Analysis}

\author{
Hilde Oliver $^{1,2}$ (D), Renato M. Castelao ${ }^{2}$ (D), Chuning Wang ${ }^{3}$ (D), and Patricia L. Yager $^{2}$ (iD \\ ${ }^{1}$ Department of Applied Ocean Physics and Engineering, Woods Hole Oceanographic Institution, Woods Hole, MA, USA, \\ ${ }^{2}$ Department of Marine Sciences, University of Georgia, Athens, GA, USA, ${ }^{3}$ Department of Marine and Coastal Sciences, \\ Rutgers, The State University of New Jersey, New Brunswick, NJ, USA
}

\begin{abstract}
As mass loss from the Greenland Ice Sheet accelerates, this modeling study considers how meltwater inputs to the ocean can impact marine ecosystems using a simplified fjord scenario. At marine-terminating glaciers in Greenland fjords, meltwater can be delivered far below the sea surface, both as subglacial runoff (from atmosphere-driven surface melt) and as basal melt (from ocean heat). Such delivery can result in buoyancy-driven upwelling and the upward entrainment of nutrient-rich deep water, which can support phytoplankton growth in fjord surface waters. For this study, we use an idealized fjord-scale model to investigate which properties of glaciers and fjords govern the transport of buoyantly upwelled nutrients from fjords. We model the influence of fjord geometry, hydrology, wind, tides, and phytoplankton growth within the fjord on meltwater-driven nutrient export to the ocean. We use the Regional Ocean Modeling System (ROMS) coupled to a buoyant plume model and a biogeochemical model to simulate physical and biogeochemical processes within an idealized tidewater glacial fjord. Results show that meltwater-driven nutrient export increases with larger subglacial discharge rates and deeper grounding lines, features that are both likely to change with continued ice sheet melting. Nutrient export decreases with longer residence times, allowing greater biological drawdown. While the absence of a coastal current in the model setup prevents the downstream advection of exported nutrients, results suggest that shelf-forced flows could influence nutrient residence time within fjords. This simplified model highlights key uncertainties requiring further observation to understand ecological impacts of Greenland mass loss.
\end{abstract}

Plain Language Summary The Greenland Ice Sheet is shrinking rapidly, in part due to atmospheric warming that melts the ice, producing meltwater runoff. At marine-terminating glaciers, the meltwater flows out to sea from underneath the foot of the glacier, resulting in buoyant plumes that rise toward the sea surface. Deep, nutrient-rich seawater can be caught up in these plumes and transported to shallower depths where it provides fertilizer for phytoplankton at the base of the food web. Processes controlling the distribution of these nutrients are poorly understood, especially when determining whether ecosystem impacts are within or outside fjords. For this study, we simulate physical and biological processes within an idealized Greenland fjord. We run multiple simulations varying the fjord's geometry, model forcing, initial condition, and biological parameters to examine how modeled nutrient transport through fjords varies under different conditions. In our simulations, we find that the fate of the nutrients is influenced by characteristics modifying the plume residence time and the exchange of water between the ocean and the fjord. Critical controls include the glacier depth and the subglacial discharge rate, which are both likely to change with continued Greenland melting. Our study highlights the need for more observations of these key components.

\section{Introduction}

Accelerating mass losses of the Greenland Ice Sheet (Mouginot et al., 2019; Shepherd et al., 2012) have motivated several recent efforts to understand how meltwater inputs to the ocean could impact coastal marine ecosystems (e.g., Cape et al., 2019; Holding et al., 2019; Hopwood et al., 2020; Meire et al., 2017). The potential biogeochemical impact of meltwater depends on, among other factors, whether the glacier is land terminating or marine terminating. At land-terminating glaciers, meltwater runoff derived from surface melting is discharged as a surface plume, which behaves similarly to a river plume (Chu et al., 2009, 2012; McGrath et al., 2010; Syvitski et al., 1985). While the meltwater discharge in surface plumes contains some elemental lithogenic nutrients (e.g., Bhatia et al., 2013; Hawkings et al., 2018; Wadham et al., 2016), nutrients may not 
be supplied at concentrations necessary to support phytoplankton blooms, and nutrient-poor meltwater can even dilute existing ocean nutrient levels (Hopwood et al., 2015, 2016; Meire et al., 2017).

At marine-terminating glaciers, meltwater is delivered deep below the surface of the ocean at the grounding depth, both as subglacial discharge (from atmospheric-driven surface melt) and as basal melt from the glacier face by the warmer ocean (Chu, 2014). These tidewater glaciers are prevalent on both the southeast and northwest coasts of Greenland (Slater et al., 2019). The delivery of meltwater at depth results in the buoyancy-driven upwelling and entrainment of nutrient-rich deeper water to the surface, where it can potentially support phytoplankton growth (Cape et al., 2019; Hopwood et al., 2018; Meire et al., 2017). The potential for buoyant upwelling to supply nutrients for phytoplankton uptake within the fjord depends, among other factors, on the depth at which the plume becomes neutrally buoyant, which depends on the depth of the glacier grounding line, the magnitude of the subglacial discharge volume flux, and the ambient stratification at the glacier face (Carroll et al., 2016). Discharge delivered too deep can reach neutral buoyancy below the euphotic depth, and thus, upwelled nutrients would be unavailable for phytoplankton uptake within the fjord (Carroll et al., 2015; 2016). Less drawdown of upwelled nutrients by phytoplankton within the fjord would increase nutrient export to the continental shelf, where it could contribute to coastal or offshore productivity.

Glaciers in Greenland typically terminate within fjords and are not in direct contact with the continental shelf (Straneo \& Cenedese, 2015). Understanding the conditions for meltwater-driven nutrient export from fjords is therefore necessary to understand the potential wider biogeochemical influence of meltwater on the coastal ocean. Buoyant upwelling of meltwater at marine-terminating glaciers occurs near the glacier front and travels toward the mouth of the fjord at the depth of neutral buoyancy (e.g., Straneo \& Cenedese, 2015). Models suggest that the export of meltwater from fjords depends on fjord width, grounding line depth, and sill height (Carroll et al., 2016, 2017). Baroclinic flows driven by density fluctuations on the shelf, or "shelf forcing," are also important to volume transport and exchange between fjords and the shelf (e.g., Jackson et al., 2014; Schaffer et al., 2020; Sutherland et al., 2014).

How meltwater-driven nutrient export varies under different fjord conditions is poorly understood, especially when considering the relative rate of nutrient uptake by phytoplankton within the fjord before export. For example, large nitrate transports are thought to occur out of Ilulissat Icefjord at the Jakobshavn Isbræ glacier terminus, where extensive ice cover is likely to reduce phytoplankton uptake of buoyantly upwelled nutrients (Cape et al., 2019). At the other extreme, no transport is thought to occur from $190 \mathrm{~km}$ long Godthåbsfjord in southwest Greenland, where primary productivity consumes most buoyantly upwelled nutrients within the fjord (Juul-Pedersen et al., 2015; Meire et al., 2017). For this study, we use a simplified, coupled ocean circulation-biogeochemical model to examine how differing fjord geometries, water column stratification, physical forcing, and biological parameterizations could affect the potential export of meltwater-driven nutrients out of fjords to the continental shelf.

\section{Methods}

\subsection{Overview}

We use a 3D, terrain-following, hydrostatic Regional Ocean Modeling System (ROMS) (Haidvogel et al., 2008) to simulate processes within an idealized fjord with features (dimensions, water mass properties, and subglacial discharge rates) similar to those observed for many SE Greenlandic systems. We model an East Greenland fjord since deep fjords are widespread in southeast Greenland (Morlighem et al., 2017) and water mass nutrient endmembers have been defined in the region (Cape et al., 2019). The model consists of a narrow fjord attached to a larger section of continental shelf, slope, and open ocean (Figures 1a and S1). To simulate the biological drawdown of nutrients within the fjord, we add a biogeochemical model with two nutrient types: nitrate and silicate. Nitrate and silicate are both modeled, as nitrogen is likely limiting to productivity in coastal systems and silicate concentration, which can be enhanced by subglacial plumes (Meire et al., 2016, 2017) and can impact phytoplankton community structure. To test the sensitivity of nutrient export from the fjord under different fjord geometries, forcing conditions, and initial vertical profiles of temperature, salinity, and nutrients, we run the model under 21 different configurations (Table 1). We assess the relative importance of the attributes varied in subsequent model configurations by comparing their output 

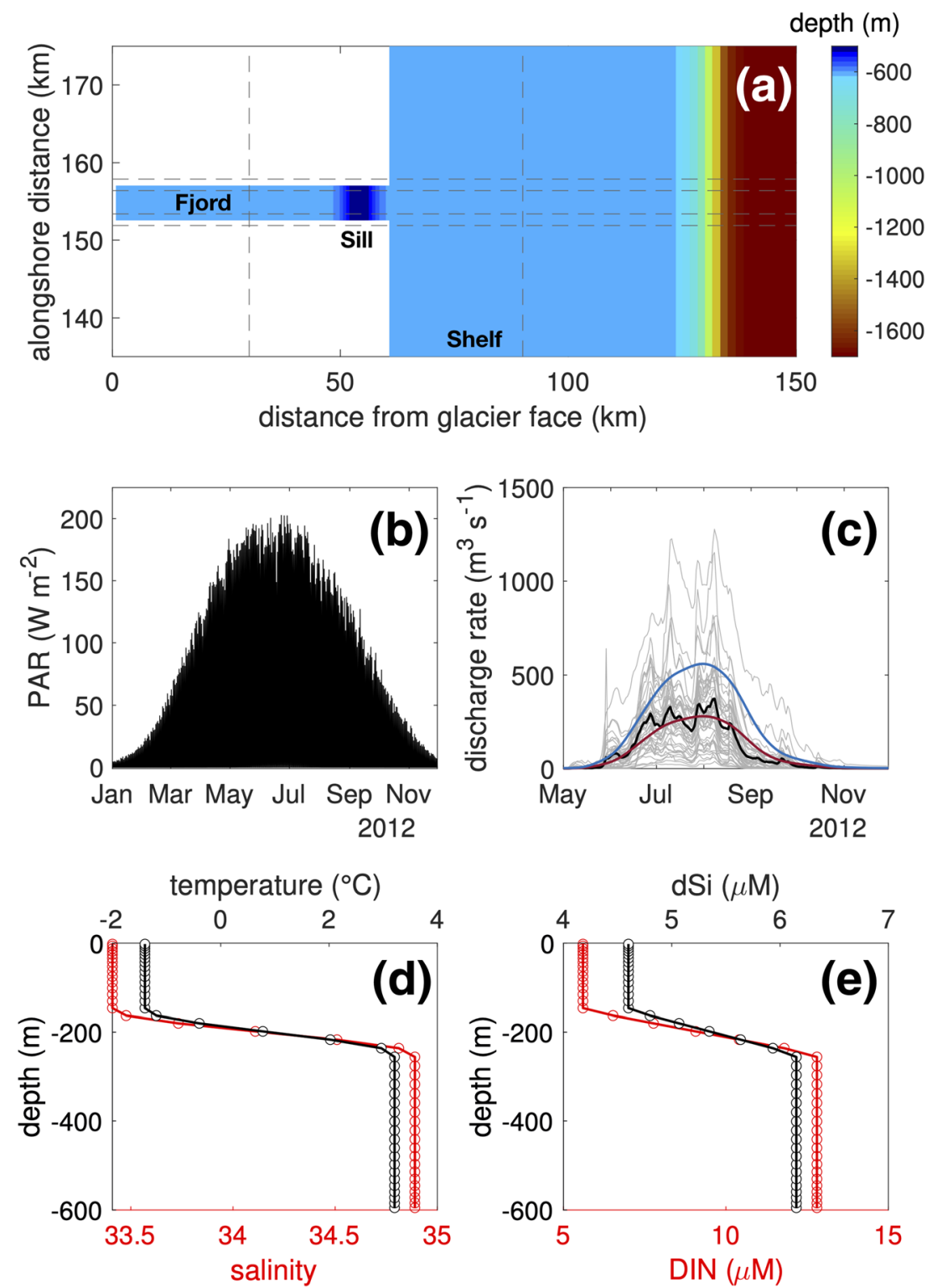

Figure 1. Model setup. (a) Close up of base case domain bathymetry, including fjord on left, continental shelf, shelf break, and open ocean on right. Vertical and horizontal dashed lines show the range of lengths and widths, respectively, used in sensitivity tests. (b) Photosynthetically active radiation (PAR) just below the surface, in $\mathrm{W} \mathrm{m}^{-2}$; (c) daily rates of discharge $\left(\mathrm{m}^{3} \mathrm{~s}^{-1}\right.$ ) for all southeast Greenland discharge points in 2012 south of $66^{\circ} \mathrm{N}$ (gray lines; $n=31$ ), the daily averages across all of the discharge points (black line), the smoothed averages used to force the base case run (red line), and the doubled smoothed discharge used to force the double discharge run (blue line, run 13); initial profiles of (d) temperature and salinity and (e) DIN and dSi for the base case.

with the base run, a $60 \mathrm{~km}$ long, $4.5 \mathrm{~km}$ wide fjord with a grounding depth of $600 \mathrm{~m}$ (similar to Sermilik Fjord near Helheim Glacier; Sciascia et al., 2013; Straneo et al., 2010) and sill depth of $500 \mathrm{~m}$.

\subsection{Model Setup and Forcing}

The along-fjord resolution of the model grid decreases telescopically ( $250 \mathrm{~m}$ at the glacier face to $750 \mathrm{~m}$ at the fjord mouth). The cross-fjord resolution is $250 \mathrm{~m}$. The model grid extends $150 \mathrm{~km}$ north and south of the fjord mouth (Figure 1a). Beyond the fjord, the grid features a $60 \mathrm{~km}$ wide continental shelf, a shelf break, and $240 \mathrm{~km}$ of open ocean. The model has 40 terrain-following layers in the vertical dimension. The model is run using generic length scale vertical mixing (Large, 1998) with a baroclinic time step of $20 \mathrm{~s}$ with 16 


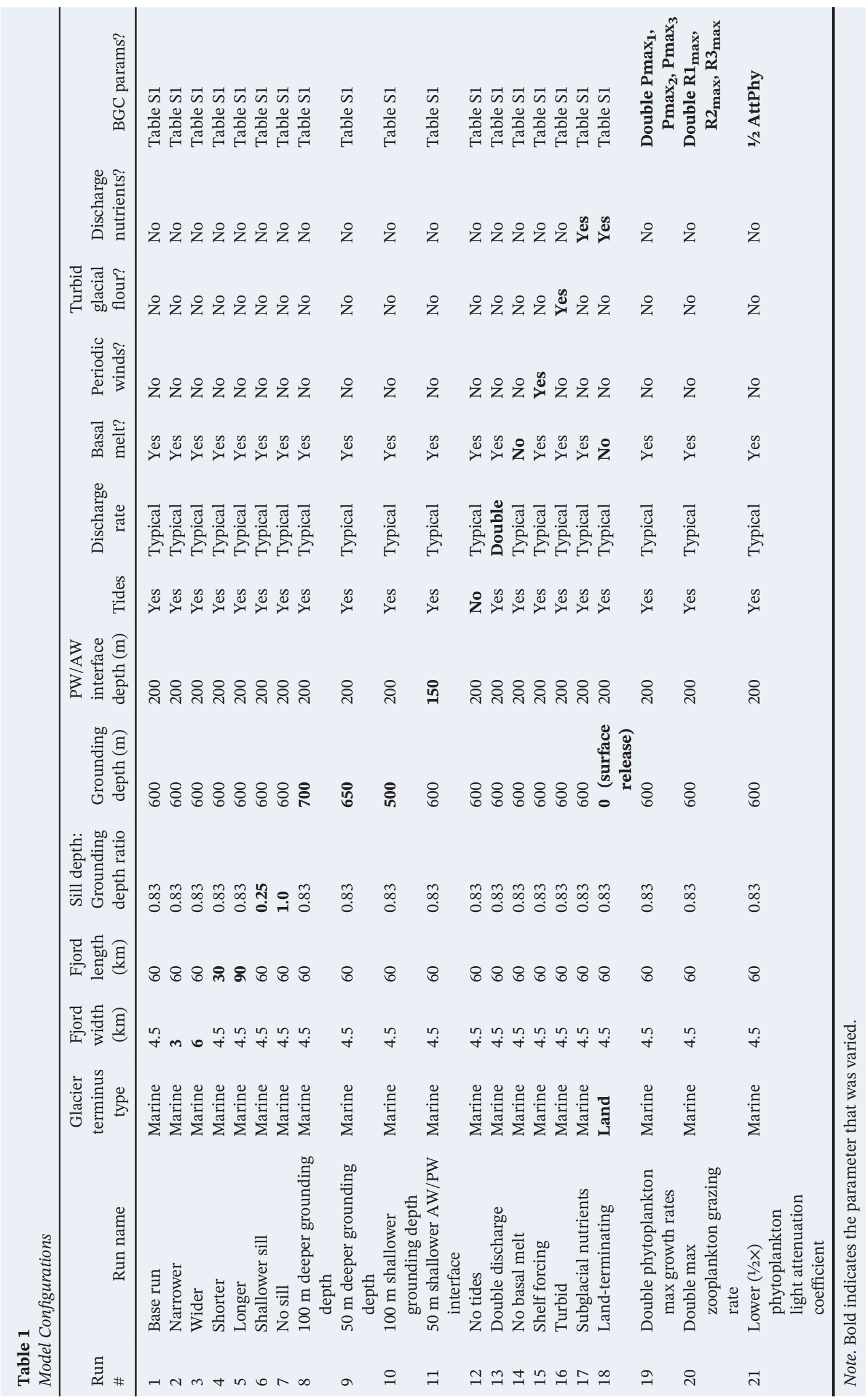


barotropic time steps between every baroclinic step. Horizontal viscosity is parameterized with the Smagorinsky scheme (Griffies \& Hallberg, 2000), and harmonic horizontal diffusivity is set to $12 \mathrm{~m}^{2} \mathrm{~s}^{-1}$ for the smallest grid cells, as in Jackson et al. (2018). The model domain is treated as an $f$ plane, with $f=1.3 \times 10^{-4} \mathrm{~s}^{-1}\left(65^{\circ} \mathrm{N}\right)$.

The model uses periodic boundary conditions at the northern and southern boundaries to avoid creating artificial alongshore pressure gradients set up by imperfect open boundary conditions (Gan \& Allen, 2002). The western boundary (at the glacier face) is closed, and the eastern boundary is open. At the open eastern boundary, we use a Flather condition for 2D momentum, a Chapman condition for the free surface, and a modified radiation condition for 3D momentum, temperature, and salinity (Marchesiello et al., 2001, 2003).

The rates of subglacial discharge at the glacier terminus are determined from an ice sheet surface elevation model (Howat et al., 2014) — the same discharge rates used for Luo et al. (2016), Arrigo et al. (2017), Oliver et al. (2018), and Castelao et al. (2019). For the base case, we use 2012 daily discharge rates, averaged for all SE Greenland discharge points south of $66^{\circ} \mathrm{N}(n=31$; Figure 1c) and smoothed with the locally weighted scatterplot smoothing (LOWESS) method. In the base case, discharge peaks at $280 \mathrm{~m}^{3} \mathrm{~s}^{-1}$, on 31 July 2012.

The initial condition of the model ocean uses an idealized two-layer stratification (Figures 1d and 1e): a cold and fresh layer of low-nutrient polar water (PW) overlying warm and salty, high-nutrient Atlantic water (AW), as has been documented and previously modeled in Sermilik Fjord near Helheim Glacier (Sciascia et al., 2013; Straneo et al., 2010). Temperature, salinity, nitrate, and silicate endmember values of these two water masses are the same as used in Cape et al. (2019). Phytoplankton, zooplankton, and detritus inventories are initialized at $10^{-3} \mu \mathrm{M}$. We then run the model for 1 January 2012 to 7 May 2012, the period when mean 2012 subglacial discharge is $<1 \mathrm{~m}^{3} \mathrm{~s}^{-1}$. After this spin-up period, we introduce subglacial discharge and basal melting at the glacier face and run the model from 7 May 2012 to 30 November 2012.

To simulate nonhydrostatic discharge plume dynamics, we use the ICEPLUME module for ROMS, modified from the IcePlume package for Massachusetts Institute of Technology General Circulation Model (Cowton et al., 2015). The ICEPLUME module allows us to use buoyant plume theory to approximate the subglacial discharge forcing as a half-conical buoyant plume. The module allows subglacial discharge, submarine meltwater, and entrained waters to be distributed over the vertical layers where the plume becomes neutrally buoyant at the glacier face. The buoyant plume model parameters are the same as used in Cowton et al. (2015), except for the drag coefficient Cd (set to 0.065, Ezhova et al., 2018). The release of basal meltwater from the thermodynamic melting of the ice sheet is calculated using the same boundary layer parameterization as the plume melting (Cowton et al., 2015), but with a drag coefficient value of 0.0025 and a minimum background velocity of $0.1 \mathrm{~m} \mathrm{~s}^{-1}$ to maintain a minimum amount of melting. The base case uses a half-conical plume, which has been shown to produce realistic entrainment factors (ratio of entrained volume to discharge volume) when compared with values determined using noble gas observations made during peak discharge season in Sermilik Fjord (Hopwood et al., 2018).

The model is also forced with atmospheric data from the European Centre for Medium-Range Weather Forecasts (ECMWF) ERA-interim reanalysis (Dee et al., 2011). Using reanalysis data from 1979 to 2016 for coastal SE Greenland, we generated 3-hourly and daily climatologies of net shortwave radiation and surface heat fluxes, respectively, to force the model. Photosynthetically active radiation (PAR) (Figure 1b) is calculated as $0.38 \times$ net shortwave radiation, which gives subsurface PAR magnitudes similar to those calculated with a clear-sky atmospheric radiation model corrected for cloud cover and sea surface reflection (Oliver et al., 2018, their supplementary material). As most of our simulations do not include wind forcing, we nudge sea surface temperature (SST) to a monthly climatology (1980-2015) of SST from Simple Ocean Data Assimilation (SODA 3.3.1; Carton \& Giese, 2008) output to help prevent unrealistic SST values. M2 tidal amplitude and current forcing at the eastern boundary were generated with Oregon State University Tidal Prediction Software (OTPS; 0.8-m amplitude, Egbert \& Erofeeva, 2002).

\subsection{Biogeochemical Model}

Our study focuses on the transport of idealized macronutrient-like tracers within the physical model framework, so it is necessary to include a model of biological drawdown of these macronutrient-like tracers. To simulate macronutrient cycling, we couple a dissolved inorganic nitrogen (DIN), silicate (dSi), and 
light-limited nitrogen-phytoplankton-zooplankton-detritus (NPZD) ecosystem model to the physical model. The Supporting Information of this study contains the biogeochemical model schematic (Figure S2), model equations (Text S1), and model parameters (Table S1).

The biogeochemical model is adapted from the Powell NPZD (Powell et al., 2006) model published for ROMS. Glacial meltwater has been shown to enhance concentrations of silicate in addition to nitrate (Meire et al., 2016, 2017), so we modify the Powell NPZD model by adding a silicon cycle. The modified biogeochemical model also includes two more phytoplankton classes (to make three phytoplankton classes in total: one silicate-using microphytoplankton [e.g., diatom] "phytoplankton 1"; one nonsilicate-using microphytoplankton [e.g., prymnesiophyte] "phytoplankton 2"; and one nonsilicate-using picoplankton class, "phytoplankton 3") and a second size-specific detrital pool (Figure S2). While large inputs of iron have also been measured in glacial meltwater (Bhatia et al., 2013; Hopwood et al., 2016), iron is unlikely to be a limiting nutrient for productivity on this spatial scale, and the development of an iron model with adequate complexity to capture dissolved iron removal processes within a fjord (Tagliabue et al., 2016) is beyond the scope of the present study.

\subsection{Model Cases}

Runs varying the fjord geometry, initial condition, tidal forcing, or biogeochemical parameters require their own spin-up period. These runs include those modifying fjord width (3-6 km; Bartholomaus et al., 2016; Carroll et al., 2016), fjord length (30-90 km; Gladish et al., 2015; Mortensen et al., 2011; Sutherland et al., 2014), sill depth (0.25-1.0; set as the ratio between the sill depth and the grounding depth as done by Carroll et al., 2017), grounding depth (500-700 m; Hopwood et al., 2018; Sutherland et al., 2014), and depth of the PW/AW interface (150-200 m; Straneo et al., 2011) (Table 1). The test removing tidal forcing also requires its own spin-up period.

Simulations using the spin-up period from the base case include those that double the discharge volume flux rate, turn off the basal melting across the grid points at the glacier face, add periodic alongshore wind forcing (6.2-day period: 12 tidal cycles, amplitude $0.2 \mathrm{~N} \mathrm{~m}^{-2}$ as done in Jackson et al., 2018), release glacial flour in the discharge plume (using default noncohesive sediment parameters in ROMS, with a suspended sediment concentration of $1,000 \mathrm{mg} \mathrm{L} \mathrm{L}^{-1}$, Overeem et al., 2017, with an attenuation coefficient AttSed $=0.065 \mathrm{~m}^{-1}\left(\mathrm{mg} \mathrm{L}^{-1}\right)^{-1}$, McSweeney et al., 2017), add dissolved inorganic nutrients to the subglacial discharge (1.5- $\mu \mathrm{M}$ DIN and 31- $\mu \mathrm{M}$ dSi; Meire et al., 2016), and release the discharge from the surface, as from a land-terminating glacier (over the top $20 \mathrm{~m}$ ) rather than from the depth of the grounding line (Table 1). To examine the sensitivity of the export to biogeochemical cycling, we conduct three additional model runs while (1) doubling maximum phytoplankton growth rates, (2) doubling maximum zooplankton grazing rates, and (3) halving the phytoplankton light attenuation coefficient.

We also investigate interactions between some model characteristics. Computing time prevents a full multivariate exploration, so we focus on a few key combinations. The grounding line depth and discharge rate are both affected by oceanic and atmospheric warming (e.g., Fettweis et al., 2013; Millan et al., 2018; Morlighem et al., 2017), so we test the sensitivity of the modeled yearly DIN transport when covarying these climate-sensitive parameters with a series of model runs with grounding lines 600, 500, 400, and $300 \mathrm{~m}$ deep and with discharge rates $1 \times, 1.5 \times, 2 \times, 2.5 \times$, and $3 \times$ the discharge rate in the base case.

\subsection{Analysis}

We used time series of tracer concentrations (salt, temperature, nutrients) and outflow velocities at the fjord mouth to explore the evolution of tracer transport over depth and time. All time series used in this study are calculated from 12.42-h average output to remove the M2 tidal influence on outflow velocities. We also consider the along-fjord cross sections, averaged across time (across each time point in August) and across the width of the fjord. Similar cross-fjord transports have been calculated with observations from Sermilik Fjord (Cape et al., 2019), making this a useful metric for comparison.

We calculate the time- and depth-integrated "yearly" DIN transport out of the fjord (in Gg) as the product of $u$ (along-fjord velocity) and DIN in the PW layer where there is a positive DIN anomaly relative to the shelf, integrated over the cross-sectional area of the fjord mouth, then summed over the model period (12 May to 30 November). We term these transports as "yearly" because transports from 1 January to 11 May and in 

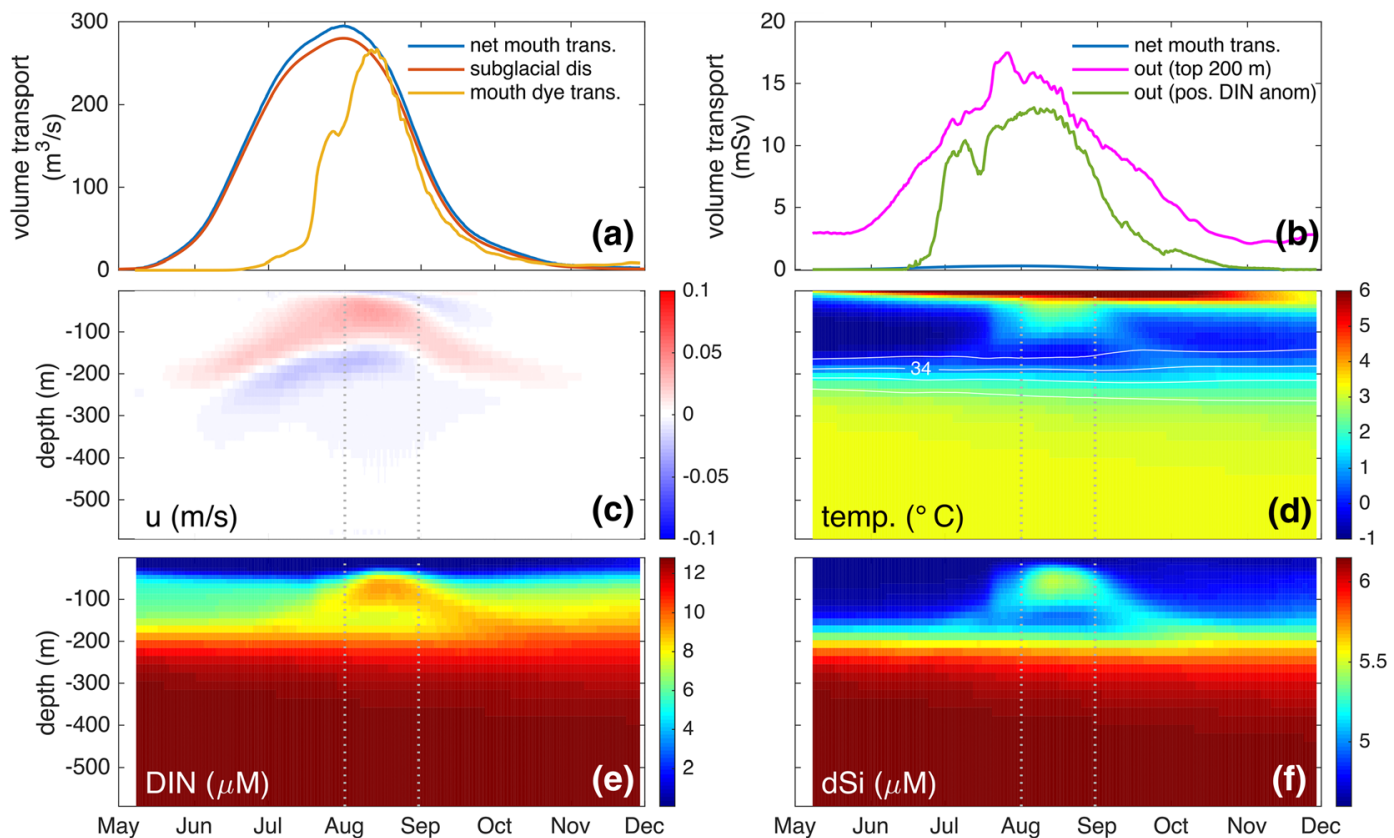

Figure 2. Temporal changes in water column properties at the mouth of the fjord (12.42-h averages: M2 de-tided) for base case model output. (a) The net volume transport at the fjord mouth (blue line), the rate of subglacial discharge (red line), and the transport of the subglacial discharge passive tracer from the fjord mouth (yellow line). (b) The net volume transport at the fjord mouth, blue line, same as in (a), the outward volume transport in the top $200 \mathrm{~m}$ (magenta line), and the outward volume transport of water carrying enhanced DIN concentrations relative to the shelf in the top $200 \mathrm{~m}$ (green line). Note that the scale on the $y$ axis changes from (a) to (b). (c-f) Temporal changes at the fjord mouth as a function of time and depth (cross-sectionally averaged). (c) $u$ (outward) velocities, with red indicating flow out the fjord and blue indicating flow toward the glacier face; (d) modeled temperature, with 0.3 isohalines; (e) modeled DIN concentrations; (f) modeled dSi concentrations. August dates (used for Figure 3) are highlighted by the gray dotted lines on (c) to (f). Plots of anomalies and expanded surface views are available in Figure S3.

December are expected to be small, as meltwater fluxes are generally low during this period in this model system.

\section{Results}

\subsection{Base Case}

The introduction of subglacial discharge sets up a typical estuarine circulation within the model fjord, with the discharge volume flux controlling the exchange between the fjord and the shelf (Figures $2 \mathrm{a}$ and $2 \mathrm{~b}$ ). Consistent with mass conservation, the modeled net volume transport out of the fjord in the base model is nearly equal to the subglacial discharge volume flux over the melt season; the difference is the volume flux contribution by basal melt (Figure 2a; red and blue lines, respectively). The subglacial discharge (transporting a dye; Figure 2a; yellow line) appears at the mouth, but with a temporal delay: export of subglacial discharge does not occur until the subglacial discharge volume reaches $\sim 200 \mathrm{~m}^{3} \mathrm{~s}^{-1}$ (Figure 2a, red line). Overall, the glacial discharge (and net transport; Figure $2 \mathrm{~b}$; blue line) is small compared with the larger outflux of the fjord circulation (Figure 2b; magenta line). When subglacial discharge peaks on 31 July (at $0.28 \mathrm{mSv}, 1 \mathrm{mSv}=1,000 \mathrm{~m}^{3} \mathrm{~s}^{-1}$ ), the modeled volume transport out of the fjord is a factor of $\sim 40$ greater than the subglacial discharge volume flux.

The impact of meltwater on fjord circulation can be visualized by examining the fluxes at the mouth of the fjord through time (Figures 2c-2f; anomalies and expanded surface views available in Figure S3). As subglacial discharge increases over June and July (Figure 2a, red line), the outflow shallows and intensifies (Figure 2c). When subglacial discharge export is highest in August (Figure 2a, yellow line), outflow velocities peak (Figure 2c) and outflow nutrient concentrations are highest (Figures 2e and 2f). This period of high 

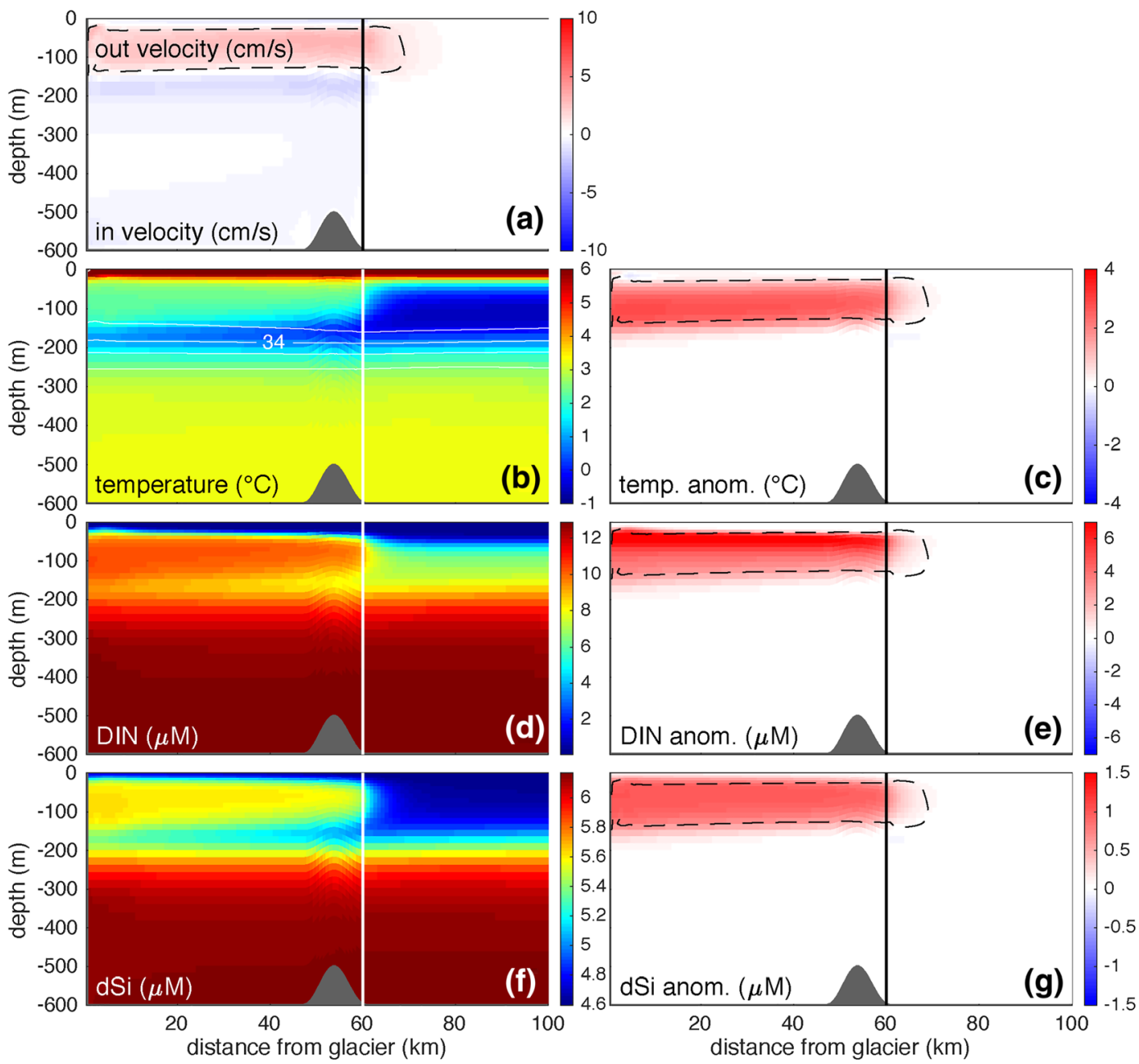

Figure 3. Along-fjord cross sections of base case model output: August monthly averages. (a) $u$ (along-fjord) velocities, with red indicating flow out the fjord and blue indicating flow toward the glacier face; (b) modeled temperatures, with 0.3 isohalines; (c) temperature anomaly relative to the shelf; (d) modeled DIN concentration; (e) DIN concentration anomaly relative to the shelf; (f) modeled dSi concentration; and (g) dSi concentration anomaly relative to the shelf. The dashed black contours in (a), (c), (e), and (g) show where the positive velocities out of the fjord in (a) are $>1 \mathrm{~cm} / \mathrm{s}$. The gray shaded regions show the location of the fjord sill. The fjord mouth is shown by the vertical lines at $60 \mathrm{~km}$.

nutrient concentrations in the fast and shallower outflow lasts for less than a month: by September, while nutrients are still enhanced at the mouth, outflow velocities are low.

Like the subglacial dye export (Figure 2a; yellow line), the outflow volume flux does not carry enhanced DIN concentrations relative to the shelf until late July, also peaking in mid-August (Figure 2b; green line). The lag in the arrival of the meltwater signal at the fjord mouth is consistent with the small modeled outflow velocities before peak discharge $\left(\sim 2 \mathrm{~cm} \mathrm{~s}^{-1}\right)$ : for a $60 \mathrm{~km}$ long fjord, it takes $\sim 35$ days for the signal to be transported from the glacier face to the fjord mouth. This enhanced DIN outflow dips for several days in mid-July (Figure 2b; green line), as the subsurface outflow transitions to a near-surface outflow (Figure 2c). This dip in the outflow is the period between the time the plume reaches the surface at the glacier face (a near immediate impact to the volume transport, Figure 2c) and the time the warmer and nutrient-rich shallower outflow reaches the fjord mouth after being advected across the length of the fjord (Figures 2d-2f).

The impact of glacial meltwater along the fjord can be seen at peak discharge in August (Figure 3), when the discharge plume reaches the fjord mouth (see Figure 2a). The base model shows the classical fjord circulation of a thick ( $400 \mathrm{~m})$ and slow inflow of warmer, saltier AW over the sill and near the bottom, with a thinner $(\sim 150 \mathrm{~m})$ and faster surface outflow of glacially modified water (Figures 3a and $3 \mathrm{~b})$. Comparing the 
Table 2

Yearly Integrated DIN Transports Out of the Fjord (in $G g$ year $^{-1}$ ) for All Sensitivity Runs

\begin{tabular}{|c|c|c|c|}
\hline $\begin{array}{l}\text { Run } \\
\#\end{array}$ & Characteristic & $\begin{array}{c}\text { Yearly DIN } \\
\text { transport } \\
\left(\mathrm{Gg}_{\text {year }}{ }^{-1}\right)\end{array}$ & $\begin{array}{l}\text { Difference } \\
\text { from base case }\end{array}$ \\
\hline 1 & Base case & 7.5 & \\
\hline 2 & Narrower & 9.0 & $20 \%$ \\
\hline 3 & Wider & 7.0 & $-7 \%$ \\
\hline 4 & Shorter & 9.7 & $29 \%$ \\
\hline 5 & Longer & 5.1 & $-32 \%$ \\
\hline 6 & Shallower sill & 5.3 & $-29 \%$ \\
\hline 7 & No sill & 7.6 & $0 \%$ \\
\hline 8 & $100 \mathrm{~m}$ deeper grounding depth & 14 & $85 \%$ \\
\hline 9 & $50 \mathrm{~m}$ deeper grounding depth & 11 & $45 \%$ \\
\hline 10 & $\begin{array}{l}100 \text { m shallower grounding } \\
\text { depth }\end{array}$ & 4.8 & $-36 \%$ \\
\hline 11 & $\begin{array}{l}50 \mathrm{~m} \text { shallower } \mathrm{AW} / \mathrm{PW} \\
\text { interface }\end{array}$ & 11 & $46 \%$ \\
\hline 12 & No tides & 7.5 & $0 \%$ \\
\hline 13 & Double discharge & 13 & $71 \%$ \\
\hline 14 & No basal melt & 7.4 & $-2 \%$ \\
\hline 15 & Shelf forcing & 7.0 & $-7 \%$ \\
\hline 16 & Turbid & 8.2 & $9 \%$ \\
\hline 17 & Subglacial nutrients & 7.6 & $0 \%$ \\
\hline 18 & Land terminating & 0.0 & $-100 \%$ \\
\hline 19 & $\begin{array}{l}\text { Double phytoplankton max } \\
\text { growth rates }\end{array}$ & 7.5 & $0 \%$ \\
\hline 20 & $\begin{array}{l}\text { Double max zooplankton } \\
\text { grazing rate }\end{array}$ & 7.5 & $0 \%$ \\
\hline 21 & $\begin{array}{l}\text { Lower }(1 / 2 \times) \text { phytoplankton } \\
\text { light attenuation coefficient }\end{array}$ & 6.7 & $-11 \%$ \\
\hline
\end{tabular}

Note. Run 1 is the base run. Figures for the shaded cases are shown in Figure 4; all cases are shown in Figure S4. conditions just inside the fjord to the ocean conditions outside the fjord reveals the extent of modification by glacial meltwater. Mixing up of the AW up into the PW occurs near the glacier face (Figures 3b, 3d, and 3f), resulting in higher temperatures and higher DIN and dSi concentrations compared with the continental shelf (Figures $3 \mathrm{c}, 3 \mathrm{e}$, and $3 \mathrm{~g}$ ). Plume temperatures in the fjord are $>2^{\circ} \mathrm{C}$ higher than offshore surface waters (Figures $3 \mathrm{~b}$ and $3 \mathrm{c}$ ). The surface plume is also richer in DIN $(>8 \mu \mathrm{M})$ and dSi $(>5 \mu \mathrm{M})$ than offshore waters (Figures $3 \mathrm{~d}-3 \mathrm{~g}$ ). This enhanced DIN in the outflow results in a yearly DIN transport of $7.5 \mathrm{Gg} \mathrm{N}$ from the fjord mouth; over $40 \%$ of the transport occurs during August.

DIN is more limiting to phytoplankton growth in the model than $\mathrm{dSi}$, so unlike DIN, dSi is not drawn down to limiting concentrations (Figures $2 \mathrm{f}$ and $\mathrm{S} 3 \mathrm{M}-\mathrm{P}$ ). Since the modeled dSi is not drawn down to 0 , we focus the remainder of the study on the DIN outflow, with DIN representing a general macronutrient tracer.

\subsection{Critical Dependencies}

The yearly DIN transport out of the fjord $(7.5 \mathrm{Gg} \mathrm{N}$ in the base case, Table 2) is most influenced by changing the grounding depth $(+85 \%,+45 \%$, and $-36 \%$ for a $100 \mathrm{~m}$ deeper, $50 \mathrm{~m}$ deeper, or $100 \mathrm{~m}$ shallower grounding depth, respectively), doubling the discharge rate (+71\%), decreasing the depth of the AW/PW interface by $50 \mathrm{~m}$ $(+46 \%)$, modifying the fjord length $(-32 \%$ or $+29 \%$ for a $50 \%$ longer or shorter fjord, respectively), decreasing the sill depth ( $-29 \%$ for a $350 \mathrm{~m}$ shallower sill), and reducing the fjord width by $50 \%(+20 \%)$ (Figure 4, Table 2; the runs selected for Figure 4 showed the most variability between runs; all other runs are displayed in Figure S4). Small impacts on the integrated DIN transport ( $<10 \%$ difference) result when widening the fjord by $50 \%$, including periodic shelf forcing, adding subglacial nutrients, adding turbid suspended sediment, or when removing tidal forcing, basal melt, and the already deep sill (Table 2; Figure S4). Releasing the discharge from the surface, like runoff from a land-terminating glacier, completely eliminates the yearly DIN transport out of the fjord (Figure 4, run 18), even with nutrients in the runoff.

Factors underlying differences in yearly DIN transports (Figure 4a) between runs can be elucidated by decomposing the transport into the volume transport at the fjord mouth (Figure $4 \mathrm{~b}$ ) and the DIN concentrations in the outflow (Figure 4c). Both volume transport and DIN concentrations are sensitive to the entrainment occurring at the glacier face, which influences the fjord exchange flow. Entrainment is highly influenced by grounding depth, discharge rate, and AW/PW interface depth; runs modifying these conditions (e.g., 8, 13, and 11) see large impacts on the yearly DIN transport. Note that the plume outflow depth when applying a doubled discharge rate is shallower, but still subsurface; nutrients have been drawn down closer to zero over these shallower depths (Figure 4d, run 13). Therefore, while August outflow DIN concentrations are not as high as in the base case (Figures $4 \mathrm{c}$ and $4 \mathrm{~d}$, run 13), DIN concentrations are enhanced closer to the surface with doubled discharge.

Entrainment is also impacted when using a sill shallower than the AW/PW interface: despite similar volume transports (Figure 4b, run 6), AW cannot as easily flow toward the glacier face (Figure 4d, run 6), so less AW is entrained in the plume and outflow DIN concentrations are depleted relative to the base case (Figures $4 \mathrm{c}$ and 4d, run 6).

While inclusion of periodic shelf forcing in the model greatly increases 12.42-hourly averaged volume fluxes (Figure 4b, run 15), the transports averaged over the forcing period (6.21 days) are similar to the base case, so there is only a small impact on the yearly DIN transport (Figure 4a, Table 2). Our choice of periodic 

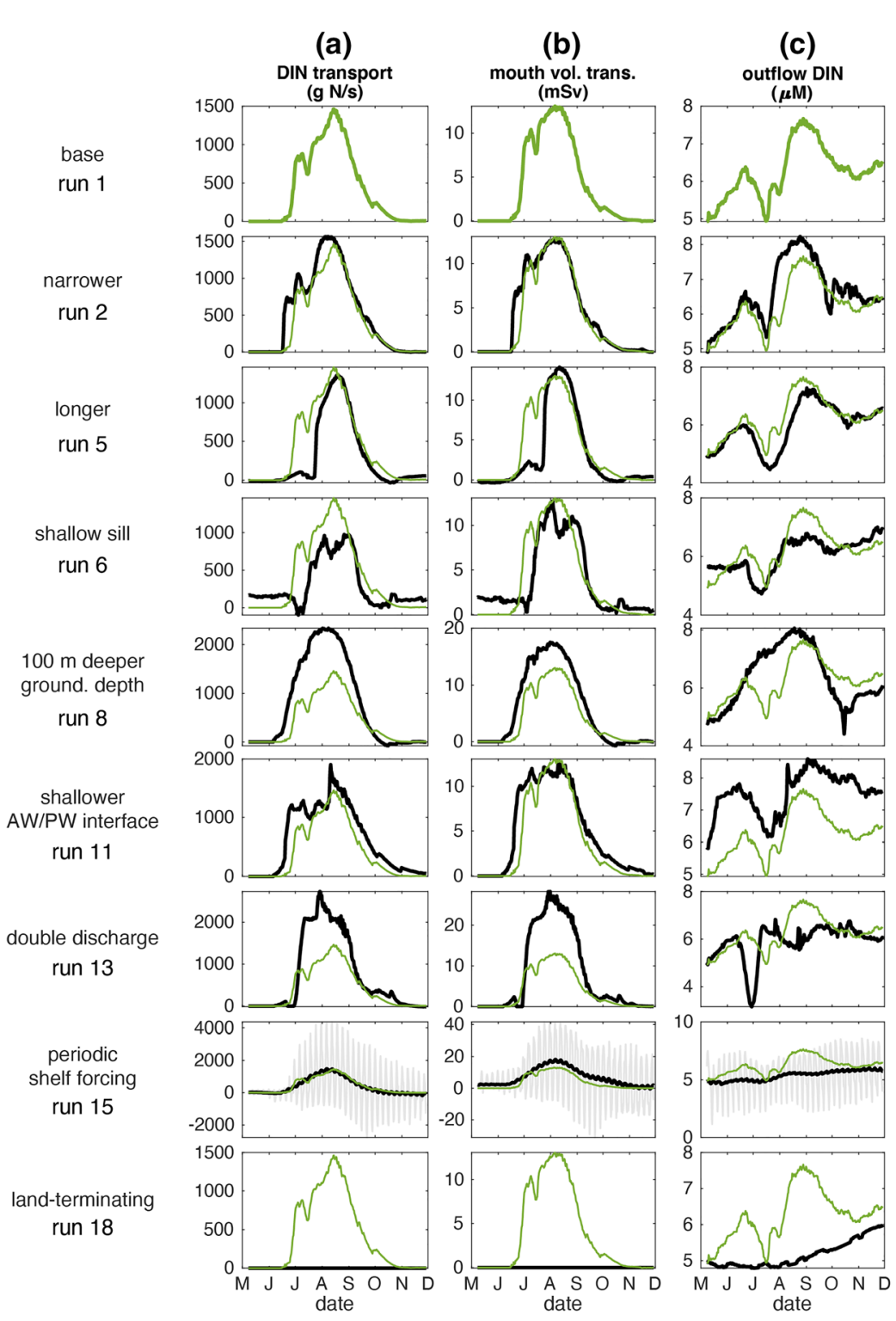

(d)

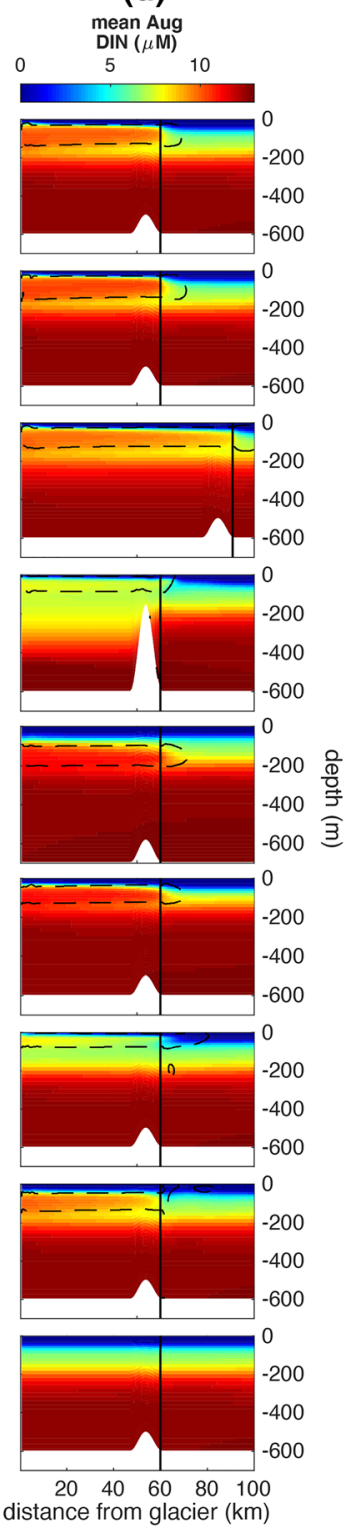

Figure 4. Model output for selected sensitivity runs (run number under description on left; showing output from runs highlighted in Table 2). (a-c) Time series from the top $200 \mathrm{~m}$ at fjord mouth: green lines show output for the base case; black lines show output from the sensitivity runs. Note that in some cases, the sensitivity run output is nearly superimposed on the base case output. In the periodic shelf forcing case (run 15), 12.42-h average is shown by the gray lines while the black lines show the output averaged over the 6.21-day forcing period. (a) The DIN transport; (b) the volume transport component of the DIN transport (as in Figure 2b); (c) the mean DIN concentration of the outflow; and (d) along-fjord cross sections of mean DIN concentrations in August (as in Figure 3d), with dashed black contours showing where the positive velocities out of the fjord are $>1 \mathrm{~cm} / \mathrm{s}$. A similar figure containing all other sensitivity runs is available in the Figure S4. In the base case row, (b) and (d) show the same data shown in Figures $2 \mathrm{~b}$ and $3 \mathrm{~d}$, respectively.

boundary conditions excludes a coastal current and results in the re-entry of exported nutrients back into the fjord (Figure 4a, run 15), when in reality, they would likely be transported downstream. This transport of nutrients out and then back into the fjord results in relatively small differences to the yearly integrated DIN transport $(-7 \%)$ and the timing of the transport. 
The importance of the upwelled DIN residence time to export likelihood is evidenced by the runs modifying the fjord length and width. The total volume transport is not strongly impacted by the fjord width (Figure 4b, run 2) with the wider fjord still narrower than the internal deformation radius $(\sim 7.3 \mathrm{~km})$; outflow velocities are necessarily higher in narrower fjords. Upwelled plume DIN in narrower fjords thus reaches the fjord mouth more quickly; less is consumed by phytoplankton (Figures $4 \mathrm{c}$ and $4 \mathrm{~d}$, run 2). Increasing the fjord length reduces the DIN transport somewhat by increasing the plume residence time. Increasing the period of biological drawdown during transport to the fjord mouth results in smaller DIN concentrations in the modeled outflow of longer fjords (Figures $4 \mathrm{c}$ and $4 \mathrm{~d}$, run 5). The bulk of the reduction in DIN transport with increasing fjord length is owed to the delayed outflow period relative to the base case (Figure 4b, run 5). For a $90 \mathrm{~km}$ long fjord, the transit time of a $2 \mathrm{~cm} \mathrm{~s}^{-1}$ outflow increases by nearly 20 days, abbreviating the period of DIN transport to the shelf (Figure 4a, run 5).

The importance of the DIN residence time in the fjord increases with faster biological drawdown: more nutrient use within the fjord reduces its export to the shelf. When doubling the phytoplankton maximum growth rate or the maximum grazing rate, there was a $<1 \%$ change to the total yearly DIN transport (7.5 Gg year ${ }^{-1}$, Table 2). Halving the phytoplankton light attenuation coefficient, however, results in an $11 \%$ decrease in yearly DIN transport (6.7 $\mathrm{Gg} \mathrm{year}^{-1}$, Table 2). In addition, the run including turbid glacial flour to the discharge plume (Figure S4, run 16) has higher outflow DIN concentrations, resulting in a $9 \%$ increase in the yearly DIN transport (Table 2). This result shows that light limitation reduces the ability of the phytoplankton to consume all of the buoyantly upwelled nitrate and that nutrient export also depends on light levels within the fjord. In the model base case, the bulk of the outflow of enhanced DIN is deeper than the predischarge or offshore nitracline depth of $\sim 50 \mathrm{~m}$ (see Figures 2e and 3d), suggesting that light levels are insufficient within the model fjord at the plume outflow depths to allow for the uptake of most of the upwelled DIN during advection from the glacier face to the fjord mouth. We note that while ice cover effects are not considered in the model for simplicity, light limitation in fjords with a large ice mélange (covering about $20 \mathrm{~km}$ in Sermilik Fjord, Straneo et al., 2016) is likely to be even greater than modeled here.

\subsection{Compounding Impacts}

The modeled DIN transport and plume outflow depth are sensitive to both the grounding line depth and discharge rate (Table 2, Figure 4), which are both affected by oceanic and atmospheric warming (e.g., Fettweis et al., 2013; Millan et al., 2018; Morlighem et al., 2017). To test the sensitivity of the modeled yearly DIN transport and mean August plume outflow depth when covarying these climate-sensitive parameters, we conduct a series of model runs with grounding lines 600, 500, 400, and $300 \mathrm{~m}$ deep and with discharge rates $1 \times, 1.5 \times, 2 \times, 2.5 \times$, and $3 \times$ the discharge rate in the base case. All other model characteristics are held as in the base case.

Modeled DIN transports grow with increasing runoff rates, but these increases decline nonlinearly and rapidly with shallower grounding line depths (Figures 5a and 5b). For a $600 \mathrm{~m}$ deep fjord, a tripling of the discharge flux increases the yearly DIN transport by more than $10 \mathrm{Gg} \mathrm{N}_{\text {year }}{ }^{-1}$. With a $500 \mathrm{~m}$ deep fjord, $3 \times$ discharge increases the DIN transport by only $5 \mathrm{Gg} \mathrm{N}_{\mathrm{Near}}{ }^{-1}$. As the grounding line approaches the nutrient-poor PW layer, the upwelling nutrient flux becomes negligible.

With initial fjord stratification held constant between simulations, increasing discharge rate and decreasing grounding depth both result in a shallower modeled plume outflow (Figure 5c). With shallower outflows, phytoplankton growth within the model plume may be less light limited, and phytoplankton nutrient drawdown could increase. We note that a larger proportional drawdown would not necessarily imply greater net community production in the fjord, as modeled plume DIN concentrations at the glacier face tend to be initially lower with shallower outflow (see Figure 4d, runs 8 and 13, and Figure S4, runs 9 and 10). When applying key model simplifications of (1) no change in initial stratification between simulations and (2) no plume turbidity and fjord ice cover, higher discharge rates could result in the modeled uptake of a larger proportion of upwelled nutrients within the fjord, while still permitting increased nutrient export (Figures 5a and 5b). 


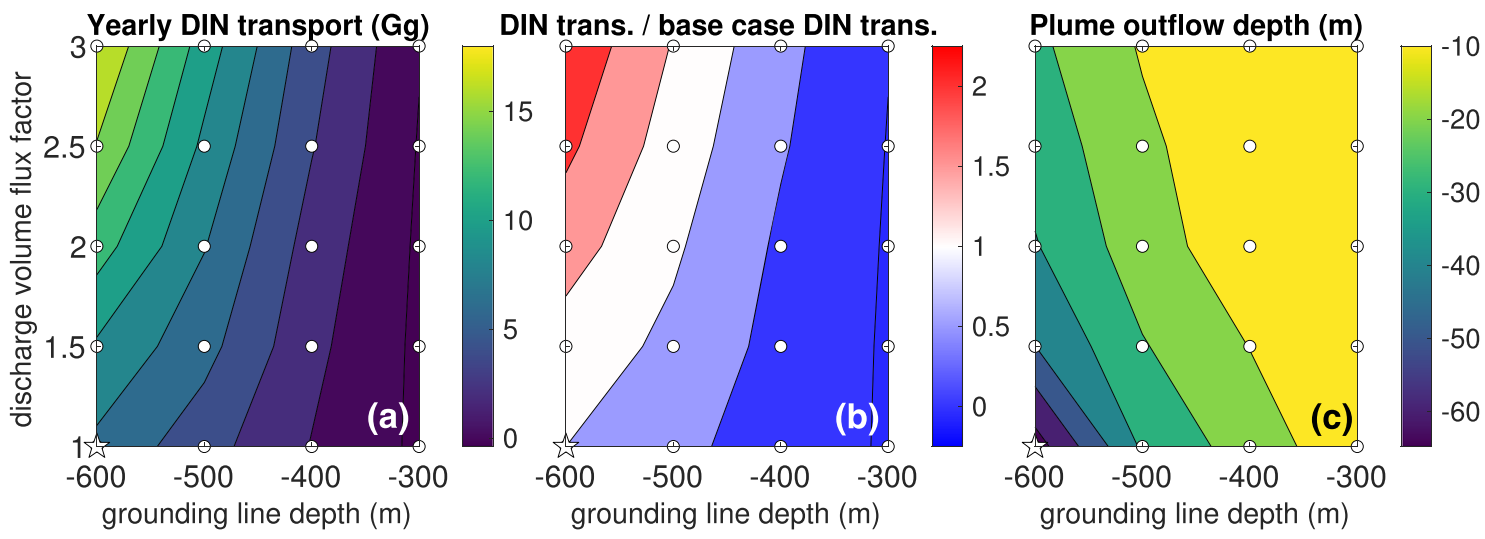

Figure 5. Model results when modifying discharge volume flux (factor indicates multiplier, e.g., $1.5 \times, 2 \times$, etc.) and the depth of the grounding line. (a) Yearly DIN transport (in Gg) out of the fjord into the shelf, (b) yearly DIN transport divided by base case transport (7.5 Gg), and (c) mean August plume outflow depth. Model combinations informing the figure are indicated by white dots, and the base case scenario is indicated by a white star.

These results suggest that the grounding line depth influences the degree to which greater subglacial discharge can increase DIN transport when the grounding line is relatively shallow, consistent with the findings of the modeling experiments conducted by Hopwood et al. (2018) and Torsvik et al. (2019). If the grounding depth is relatively deep, and all other parameters are held constant, modeled DIN export is more sensitive to discharge rate.

\section{Discussion}

\subsection{Applicability}

For this idealized sensitivity study, we tested a wide range of parameters against a base case scenario. Results from the simplified model should not be interpreted as realistic in the context of actual fjords; instead, they are meant to identify and quantify the sensitivity of nutrient transport from fjords to different glacier and fjord characteristics and forcing. Given the wide variety of fjords around Greenland, and limited biogeochemical data from most fjords, it is not yet practical to completely explore their entire parameter space.

This modeling work is most applicable to fairly deep, straight, and narrow SE Greenland glacial fjords without complicated bathymetry. Since properties of AW/PW vary around Greenland (Straneo et al., 2012), the choice of a two-layer AW/PW stratification with properties based on field measurements from Sermilik Fjord makes the model more applicable to SE Greenland.

The ratio of the internal deformation radius to the fjord width $\left(\mathrm{R}_{\mathrm{d}} / \mathrm{W}\right)$ of many well-studied fjords in Greenland is $\sim \mathrm{O}(1)$ (Jackson et al., 2018); in our analyses, $\mathrm{R}_{\mathrm{d}} / \mathrm{W}$ ranges from $\sim 0.4$ to 0.8 . In wider fjords $\left(\mathrm{R}_{\mathrm{d}} / \mathrm{W}>1\right)$, recirculation cells would likely result in larger volume transports and greater dilution of the outflow plume, which could impact the nutrient concentration and residence time of the plume (Carroll et al., 2017).

Complicated sills and fjord bathymetry may also influence fjord-shelf exchange (Carroll et al., 2017; Gladish et al., 2015). As the removal of the deep sill has a $<1 \%$ effect on the yearly DIN transport, one could also consider this series of deep-sill simulations as variations on a sill-free fjord. We further note that, while basal melting is modeled, this study focuses on subglacial discharge effects, so this model system is not applicable to those where basal melting dominates freshwater budgets, like Nioghalvfjerdsfjorden Glacier (also known as the $79^{\circ} \mathrm{N}$ Glacier) or Petermann Glacier, which are characterized by long floating ice tongues (Münchow et al., 2014; Schaffer et al., 2020).

\subsection{Comparisons}

The physics of the model presented here is generally consistent with other models of SE Greenland buoyant plumes (e.g., Carroll et al., 2015, 2017; Cowton et al., 2015; Sciascia et al., 2013). Like other buoyant plume models, the subglacial discharge in our model rises to the depth of neutral buoyancy and then flows toward the fjord mouth, with the outflow velocity increasing and the outflow depth decreasing as the discharge rate 
increases. The modeled buoyant plume location in our study is also consistent with noble gas studies tracing glacial meltwater in Greenlandic fjords, which show most subglacial discharge in the upper layers of the fjord (Beaird et al., 2015, 2018). Our study generally agrees with the study by Carroll et al. (2017), which shows the importance of the grounding line on fjord circulation. Their study shows a larger importance of tidal forcing and fjord width to the fjord circulation, though our study tests a narrower range of fjord widths, all within the deformation radius.

While the model base is somewhat fitted to Sermilik Fjord, direct comparison with nutrient measurements and transport calculations for Sermilik Fjord in Cape et al. (2019) likely reflects model simplifications. In the model base case, yearly DIN transports are $44 \%$ of those calculated for Sermilik Fjord $\left(17.1 \pm 3.9 \mathrm{Gg} \mathrm{N}_{\text {year }}{ }^{-1}\right.$, Cape et al., 2019), while the base case modeled entrainment factor is about $33 \%$ larger than observed (Beaird et al., 2018). This difference could be due to our use of an average daily discharge rate from all SE Greenland outlets, which is about a quarter of the discharge rates found in Sermilik fjord $\left(1,200 \pm 700 \mathrm{~m}^{3} \mathrm{~s}^{-1}\right.$, Jackson \& Straneo, 2016), and the use of a single discharge plume point source, when Sermilik Fjord is fed by three glaciers (Helheim, Fernis, and Midgård). Our choice of a half-cone buoyant plume parameterization could also result in less high-DIN water entrained into the plume than when using a line plume parameterization (Jackson et al., 2017).

Several other simplifications in the model may also reduce simulated DIN transport. Light levels in real fjords are likely lower than modeled; the model base case does not account for plume turbidity or ice cover. The ice mélange in Sermilik Fjord, for example, spans $\sim 20 \mathrm{~km}$, likely darkening the water column and inhibiting phytoplankton nutrient uptake. Our model may also be missing realistic nutrient contributions from upwelling of submarine meltwater. At the glacier face, the basal melt rate may be underestimated by the ICEPLUME model (Holland \& Jenkins, 1999; Sutherland et al., 2019). Recent data from LeConte Glacier, Alaska, for example, suggest that modeled basal melt rates could be $100 \times$ lower than reality (Jackson et al., 2019). Our model also does not include icebergs and iceberg melting, which can drive localized nutrient upwelling and dilute phytoplankton (Schwarz \& Schodlok, 2009; Vernet et al., 2011).

Our model results agree with other findings on the large relative importance of shelf-forced flows, or intermediary circulation, to the volume transport in the deep-silled modeled fjord (e.g., Fraser \& Inall, 2018; Jackson et al., 2014; Sutherland et al., 2014). Shelf forcing has been found to be the dominant mode of variability for fjord circulation (Jackson et al., 2014; Straneo et al., 2010) and drives an exchange that is 10× greater than the estuarine circulation (Sutherland et al., 2014). The inclusion of periodic shelf forcing has little net impact on the DIN transport, however, because the use of periodic north/south boundary conditions for this model prevents the resolution of a true coastal current. Periodic shelf forcing could nevertheless influence the residence time of nutrients within fjords, influencing their export. These impact of shelf forcing on residence time would likely change based on fjord dimension and sill height (Gladish et al., 2015; Jackson et al., 2018); modeling the plume with a coastal current is necessary to investigate these dynamics.

\subsection{Ecological Sensitivity to Glacial Melting}

Changing subglacial discharge rates and grounding depths is likely to influence primary productivity within fjords. Primary production within fjords provides critical support to higher trophic levels and is known to correlate with meltwater runoff (Arimitsu et al., 2012; Lydersen et al., 2014; Meire et al., 2017). The sensitivity of productivity to rapidly changing physical conditions therefore could have important implications for coastal ecosystems. In the extreme case, the transition to a land-terminating glacier terminus could lead to the shutdown of the nutrient pump in the fjord (Hopwood et al., 2018; Meire et al., 2017). In this study, light and nutrient limitation within fjords decreases with more subglacial discharge entraining nutrient-rich deeper water into shallower outflows, increasing modeled primary productivity while still allowing some export of nutrients in the outflow to the ocean.

The biogeochemical parameterization has an overall minor impact on the model outcome. For the base case run outflow depth, the model physics are overall a stronger control on the modeled nutrient concentrations than biogeochemical cycling in the fjord; hence, modifying maximum growth rates has little impact on the total modeled DIN transport (Table 2). With shallower outflows, the biogeochemical parameterization is likely to exert a larger influence on the model result, however. Bio-optical properties (Holding et al., 2019; Murray et al., 2015) and grazer distributions (Arendt et al., 2010, 2016; Middelbo et al., 2018) can vary 
widely both within and between fjords; the offshore, subarctic bio-optical parameters used in this study may not be realistic for real fjords (Table S1). Measurements of taxa-specific photosynthesis-irradiance parameters, grazing rates, and along-fjord light levels from a variety of Greenland fjords are therefore needed to accurately parameterize nutrient uptake and export from fjords, especially for those with outflows within the euphotic zone.

\subsection{Call for Further Observations}

To understand potential impacts of increased melting and discharge on coastal ecosystems, we need to understand the time scales of change at Greenland's calving fronts (e.g., Catania et al., 2020). Many of Greenland's tidewater glaciers rest on prograde slopes (the bed shallowing inland, Millan et al., 2018), such as Mogens Heinesen in SE Greenland and Savissuaq Glacier in NW Greenland (Morlighem et al., 2017). The least stable glaciers rest on retrograde slopes, however, where the bed deepens inland, such as Illullip Sermia and Hayes Glacier in NW Greenland (Choi et al., 2017; Millan et al., 2018; Morlighem et al., 2019). With retreat on a retrograde bed, the grounding line may also deepen. With continued grounding line retreat, about $20 \%$ of identified marine-terminating glaciers around Greenland are expected to be exposed to nutrient-rich AW, with grounding depths remaining deeper than $300 \mathrm{~m}$ after hundreds of kilometers of retreat (Morlighem et al., 2017). For these deep fjords, common to SE Greenland (Morlighem et al., 2017), deeper grounding lines could potentially increase nutrient entrainment in buoyant plumes.

This study uses an idealized SE Greenland case because AW properties are well defined in this region and we can reasonably apply the assumption that deep inflows into SE fjords carry a largely unmodified AW signature. Care must be taken not to extrapolate the results of this idealized modeling study to fjords where these assumptions no longer hold. Cross-shelf mixing and complicated sill systems in fjords could modify temperature, salinity, and nutrient profiles between the shelf and fjord, and under these conditions, upward nutrient transports derived from buoyant plume theory using shelf profiles may not be realistic. Additionally, small changes in boundary current density, likely with coastal freshening, could have large impacts on the estuarine circulation within fjords (Boone et al., 2018; Sejr et al., 2017). Increased stratification could also influence plume outflow depths and may prevent surface expression of meltwater plumes (De Andrés et al., 2020). Understanding transports from real fjords will hence require repeated measurements of properties from within and outside a wide range of fjords, as has been undertaken by the Oceans Melting Greenland (OMG) mission (Fenty et al., 2016).

Modeled nutrient entrainment and outflow depth are also sensitive to subglacial discharge rates, so further understanding of ecological sensitivity to glacial melting is likely to require consideration of short-term variability in discharge rates. Large fluctuations in discharge can occur on hourly time scales, and sudden discharge events (e.g., Kjeldsen et al., 2014) could account for a large fraction of annual discharge. There is little data currently available to quantify the frequency of such discharge events, however.

Greenland's glacial fjords are dynamic coastal ecosystems; this study attempts to understand the potential for meltwater-driven upwelling within these fjords to have biogeochemical impacts on the shelf with a simplified fjord-shelf model sensitivity study. More work is needed to understand the implications of rapid glacial melting on coastal biogeochemistry, including a more thorough examination of how the coastal current advects exported nutrients, both with and without of the presence of shelf-forced flows. Adding realistic bathymetry, discharge rates, and ice cover will also help understand more of these dynamics. In addition to physical parameters, repeated profiling of nitrate, silicate, ammonium, chlorophyll, turbidity, and PAR as well as measurements of primary productivity, grazing, and phytoplankton and zooplankton community structure within and outside a wide variety of fjords are necessary to understand the influence of Greenland meltwater on marine ecosystems.

\section{Conclusions}

The results presented are from an idealized 3D modeling study of a simplified Greenland glacial fjord and shelf that combines buoyant plume theory and biogeochemistry. We use the model to explore the effects of buoyancy-driven upwelling of nutrient-rich deep water by subglacial meltwater delivery at the base of a tidewater (marine-terminating) glacier using parameters that are comparable with many SE Greenland glacier fjord systems. We conduct a series of experiments varying fjord geometry, initial oceanic conditions, and 
model forcing. Using rates of subglacial discharge for SE Greenland, we run our model under 21 different configurations and compare the nutrient export between runs. Our results suggest that climate-sensitive conditions such as the subglacial discharge rate and the grounding line depth could influence the export of meltwater-enhanced nutrients from fjords. Factors controlling the plume residence time, such as fjord dimensions and periodic shelf forcing, could also influence modeled nutrient transports, though the exclusion of a coastal current in this model inhibits downstream advection of nutrients exported in shelf-forced flows; these dynamics remain to be explored.

\section{Data Availability Statement}

The data and reanalysis products supporting the findings of this study are publicly available online at www. ecmwf.int/en/research/climate-reanalysis/era-interim and apdrc.soest.hawaii.edu/datadoc/soda_3.3.1.php. MAR 3.2 simulations are available at www.cryocity.org/mar-explorer and www.aoncadis.org/dataset/ CPL_MAR.html. ROMS model code is available at www.myroms.org. The model results are archived at https://doi.org/10.18739/A21V5BF0Z.

\begin{abstract}
Acknowledgments
We would like to thank the three anonymous reviewers whose constructive comments significantly improved the quality of this manuscript. This project was supported by a University of Georgia Presidential Scholarship and NSF Graduate Research Fellowship (GRFP) (to HO), NASA-IDS NNX14AD98G, and by NASA Physical Oceanography program (80NSSC18K0766).
\end{abstract}

\section{References}

Arendt, K. E., Agersted, M. D., Sejr, M. K., \& Juul-Pedersen, T. (2016). Glacial meltwater influences on plankton community structure and the importance of top-down control (of primary production) in a NE Greenland fjord. Estuarine, Coastal and Shelf Science, 183, $123-135$. https://doi.org/10.1016/j.ecss.2016.08.026

Arendt, K. E., Nielsen, T. G., Rysgaard, S. S., \& Tönnesson, K. (2010). Differences in plankton community structure along the Godthåbsfjord, from the Greenland Ice Sheet to offshore waters. Marine Ecology Progress Series, 401, 49-62. https://doi.org/10.3354/meps08368

Arimitsu, M. L., Piatt, J. F., Madison, E. N., Conaway, J. S., \& Hillgruber, N. (2012). Oceanographic gradients and seabird prey community dynamics in glacial fjords. Fisheries Oceanography, 21(2-3), 148-169. https://doi.org/10.1111/j.1365-2419.2012.00616.X

Arrigo, K. R., van Dijken, G. L., Castelao, R. M., Luo, H., Rennermalm, Å. K., Tedesco, M., et al. (2017). Melting glaciers stimulate large summer phytoplankton blooms in southwest Greenland waters. Geophysical Research Letters, 44, 6278-6285. https://doi.org/10.1002/ 2017GL073583

Bartholomaus, T. C., Stearns, L. A., Sutherland, D. A., Shroyer, E. L., Nash, J. D., Walker, R. T., et al. (2016). Contrasts in the response of adjacent fjords and glaciers to ice-sheet surface melt in West Greenland. Annals of Glaciology, 57(73), 25-38. https://doi.org/10.1017/ aog.2016.19

Beaird, N., Straneo, F., \& Jenkins, W. (2015). Spreading of Greenland meltwaters in the ocean revealed by noble gases. Geophysical Research Letters, 42, 7705-7713. https://doi.org/10.1002/2015GL065003

Beaird, N. L., Straneo, F., \& Jenkins, W. (2018). Export of strongly diluted Greenland meltwater from a major glacial fjord. Geophysical Research Letters, 45, 4163-4170. https://doi.org/10.1029/2018GL077000

Bhatia, M. P., Kujawinski, E. B., Das, S. B., Breier, C. F., Henderson, P. B., \& Charette, M. A. (2013). Greenland meltwater as a significant and potentially bioavailable source of iron to the ocean. Nature Geoscience, 6(4), 274-278. https://doi.org/10.1038/ngeo1746

Boone, W., Rysgaard, S., Carlson, D. F., Meire, L., Kirillov, S., Mortensen, J., et al. (2018). Coastal freshening prevents fjord bottom water renewal in Northeast Greenland: A mooring study from 2003 to 2015. Geophysical Research Letters, 45, 2726-2733. https://doi.org/ 10.1002/2017GL076591

Cape, M. R., Straneo, F., Beaird, N., Bundy, R. M., \& Charette, M. A. (2019). Nutrient release to oceans from buoyancy-driven upwelling at Greenland tidewater glaciers. Nature Geoscience, 12(1), 34-39. https://doi.org/10.1038/s41561-018-0268-4

Carroll, D., Sutherland, D. A., Hudson, B., Moon, T., Catania, G. A., Shroyer, E. L., et al. (2016). The impact of glacier geometry on meltwater plume structure and submarine melt in Greenland fjords. Geophysical Research Letters, 43, 9739-9748. https://doi.org/10.1002/ 2016GL070170

Carroll, D., Sutherland, D. A., Shroyer, E. L., Nash, J. D., Catania, G. A., \& Stearns, L. A. (2015). Modeling turbulent subglacial meltwater plumes: Implications for fjord-scale buoyancy-driven circulation. Journal of Physical Oceanography, 45(8), 2169-2185. https://doi.org/ 10.1175/JPO-D-15-0033.1

Carroll, D., Sutherland, D. A., Shroyer, E. L., Nash, J. D., Catania, G. A., \& Stearns, L. A. (2017). Subglacial discharge-driven renewal of tidewater glacier fjords. Journal of Geophysical Research: Oceans, 122, 6611-6629. https://doi.org/10.1002/2017JC012962

Carton, J. A., \& Giese, B. S. (2008). A reanalysis of ocean climate using Simple Ocean Data Assimilation (SODA). Monthly Weather Review, 136(8), 2999-3017. https://doi.org/10.1175/2007MWR1978.1

Castelao, R. M., Luo, H., Oliver, H., Rennermalm, A. K., Tedesco, M., Bracco, A., et al. (2019). Controls on the transport of meltwater from the Southern Greenland Ice Sheet in the Labrador Sea. Journal of Geophysical Research: Oceans, 124, 3551-3560. https://doi.org/ 10.1029/2019JC015159

Catania, G. A., Stearns, L. A., Moon, T. A., Enderlin, E. M., \& Jackson, R. H. (2020). Future evolution of Greenland's marine-terminating outlet glaciers. Journal of Geophysical Research: Earth Surface, 125, e2018JF004873. https://doi.org/10.1029/2018JF004873

Choi, Y., Morlighem, M., Rignot, E., Mouginot, J., \& Wood, M. (2017). Modeling the response of Nioghalvfjerdsfjorden and Zachariae Isstrøm glaciers, Greenland, to ocean forcing over the next century. Geophysical Research Letters, 44, 11,071-11,079. https://doi.org/ 10.1002/2017GL075174

Chu, V. W. (2014). Greenland Ice Sheet hydrology: A review. Progress in Physical Geography, 38(1), 19-54. https://doi.org/10.1177/ 0309133313507075

Chu, V. W., Smith, L. C., Rennermalm, Å. K., Forster, R. R., \& Box, J. E. (2012). Hydrologic controls on coastal suspended sediment plumes around the Greenland Ice Sheet. The Cryosphere, 6(1), 1-19. https://doi.org/10.5194/tc-6-1-2012

Chu, V. W., Smith, L. C., Rennermalm, A. K., Forster, R. R., Box, J. E., \& Reehy, N. (2009). Sediment plume response to surface melting and supraglacial lake drainages on the Greenland Ice Sheet. Journal of Glaciology, 55(194), 1072-1082. https://doi.org/10.3189/ 002214309790794904 
Cowton, T., Slater, D., Sole, A., Goldberg, D., \& Nienow, P. (2015). Modeling the impact of glacial runoff on fjord circulation and submarine melt rate using a new subgrid-scale parameterization for glacial plumes. Journal of Geophysical Research: Oceans, 120, 796-812. https:// doi.org/10.1002/2014JC010324

De Andrés, E., Slater, D. A., Straneo, F., Otero, J., Das, S., \& Navarro, F. (2020). Surface emergence of glacial plumes determined by fjord stratification. The Cryosphere, 14(6), 1951-1969. https://doi.org/10.5194/tc-14-1951-2020

Dee, D. P., Uppala, S. M., Simmons, A. J., Berrisford, P., Poli, P., Kobayashi, S., et al. (2011). The ERA-Interim reanalysis: Configuration and performance of the data assimilation system. Quarterly Journal of the Royal Meteorological Society, 137(656), 553-597. https://doi.org/ $10.1002 /$ qj. 828

Egbert, G. D., \& Erofeeva, S. Y. (2002). Efficient inverse modeling of barotropic ocean tides. Journal of Atmospheric and Oceanic Technology, 19(2), 183-204. https://doi.org/10.1175/1520-0426(2002)019<0183:EIMOBO>2.0.CO;2

Ezhova, E., Cenedese, C., \& Brandt, L. (2018). Dynamics of three-dimensional turbulent wall plumes and implications for estimates of submarine glacier melting. Journal of Physical Oceanography, 48(9), 1941-1950. https://doi.org/10.1175/JPO-D-17-0194.1

Fenty, I., Willis, J., Khazendar, A., Dinardo, S., Forsberg, R., Fukumori, I., et al. (2016). Oceans Melting Greenland: Early results from NASA's ocean-ice mission in Greenland. Oceanography, 29(4), 72-83. https://doi.org/10.5670/oceanog.2016.100

Fettweis, X., Franco, B., Tedesco, M., Van Angelen, J. H., Lenaerts, J. T. M., Van Den Broeke, M. R., \& Gallée, H. (2013). Estimating Greenland ice sheet surface mass balance contribution to future sea level rise using the regional atmospheric climate model MAR. The Cryosphere, 6(4), 3101-3147. https://doi.org/10.5194/tcd-6-3101-2012

Fraser, N. J., \& Inall, M. E. (2018). Influence of barrier wind forcing on heat delivery toward the Greenland Ice Sheet. Journal of Geophysical Research: Oceans, 123, 2513-2538. https://doi.org/10.1002/2017JC013464

Gan, J., \& Allen, J. S. (2002). A modeling study of shelf circulation off northern California in the region of the Coastal Ocean Dynamics Experiment: Response to relaxation of upwelling winds. Journal of Geophysical Research, 107(C9), 3123. https://doi.org/10.1029/ 2000JC000768

Gladish, C. V., Holland, D. M., Rosing-Asvid, A., Behrens, J. W., \& Boje, J. (2015). Oceanic boundary conditions for Jakobshavn Glacier. Part I: Variability and renewal of Ilulissat Icefjord waters, 2001-14*. Journal of Physical Oceanography, 45(1), 3-32. https://doi.org/ 10.1175/JPO-D-14-0044.1

Griffies, S. M., \& Hallberg, R. W. (2000). Biharmonic friction with a Smagorinsky-like viscosity for use in large-scale eddy-permitting ocean models. Monthly Weather Review, 128(8), 2935-2946. https://doi.org/10.1175/1520-0493(2000)128<2935:BFWASL>2.0.CO;2

Haidvogel, D. B., Arango, H., Budgell, W. P., Cornuelle, B. D., Curchitser, E., Di Lorenzo, E., et al. (2008). Ocean forecasting in terrain-following coordinates: Formulation and skill assessment of the Regional Ocean Modeling System. Journal of Computational Physics, 227(7), 3595-3624. https://doi.org/10.1016/j.jcp.2007.06.016

Hawkings, J. R., Benning, L. G., Raiswell, R., Kaulich, B., Araki, T., Abyaneh, M., et al. (2018). Biolabile ferrous iron bearing nanoparticles in glacial sediments. Earth and Planetary Science Letters, 493, 92-101. https://doi.org/10.1016/j.epsl.2018.04.022

Holding, J. M., Markager, S., Juul-Pedersen, T., Paulsen, M. L., Møller, E. F., Meire, L., \& Sejr, M. K. (2019). Seasonal and spatial patterns of primary production in a high-latitude fjord affected by Greenland Ice Sheet run-off. Biogeosciences, 16(19), 3777-3792. https://doi.org/ 10.5194/bg-16-3777-2019

Holland, D. M., \& Jenkins, A. (1999). Modeling thermodynamic ice-ocean interactions at the base of an ice shelf. Journal of Physical Oceanography, 29(8), 1787-1800. https://doi.org/10.1175/1520-0485(1999)029<1787:MTIOIA>2.0.CO;2

Hopwood, M., Connelly, D. P., Arendt, K. E., Juul-Pedersen, T., Stinchcombe, M., Meire, L., et al. (2016). Seasonal changes in Fe along a glaciated Greenlandic fjord. Frontiers in Earth Science, 4(March), 1-13. https://doi.org/10.3389/feart.2016.00015

Hopwood, M. J., Bacon, S., Arendt, K., Connelly, D. P., \& Statham, P. J. (2015). Glacial meltwater from Greenland is not likely to be an important source of Fe to the North Atlantic. Biogeochemistry, 124(1-3), 1-11. https://doi.org/10.1007/s10533-015-0091-6

Hopwood, M. J., Carroll, D., Browning, T. J., Meire, L., Mortensen, J., Krisch, S., \& Achterberg, E. P. (2018). Non-linear response of summertime marine productivity to increased meltwater discharge around Greenland. Nature Communications, 9(1), 3256. https://doi.org/ 10.1038/s41467-018-05488-8

Hopwood, M. J., Carroll, D., Dunse, T., Hodson, A., Holding, J. M., Iriarte, J. L., et al. (2020). Review article: How does glacier discharge affect marine biogeochemistry and primary production in the Arctic? The Cryosphere, 14(4), 1347-1383. https://doi.org/10.5194/tc-14$1347-2020$

Howat, I. M., Negrete, A., \& Smith, B. E. (2014). The Greenland Ice Mapping Project (GIMP) land classification and surface elevation data sets. The Cryosphere, 8(4), 1509-1518. https://doi.org/10.5194/tc-8-1509-2014

Jackson, R. H., Nash, J. D., Kienholz, C., Sutherland, D. A., Amundson, J. M., Motyka, R. J., et al. (2019). Meltwater intrusions reveal mechanisms for rapid submarine melt at a tidewater glacier. Geophysical Research Letters, 47, e2019GL085335. https://doi.org/10.1029/ 2019gl085335

Jackson, R. H., Shroyer, E. L., Nash, J. D., Sutherland, D. A., Carroll, D., Fried, M. J., et al. (2017). Near-glacier surveying of a subglacial discharge plume: Implications for plume parameterizations. Geophysical Research Letters, 44(13), 6886-6894. https://doi.org/10.1002/ 2017GL073602

Jackson, R. H., Lentz, S. J., \& Straneo, F. (2018). The dynamics of shelf forcing in Greenlandic fjords. Journal of Physical Oceanography, 48(11), 2799-2827. https://doi.org/10.1175/jpo-d-18-0057.1

Jackson, R. H., \& Straneo, F. (2016). Heat, salt, and freshwater budgets for a glacial fjord in Greenland. Journal of Physical Oceanography, 46(9), 2735-2768. https://doi.org/10.1175/JPO-D-15-0134.1

Jackson, R. H., Straneo, F., \& Sutherland, D. a. (2014). Externally forced fluctuations in ocean temperature at Greenland glaciers in non-summer months. Nature Geoscience, 7(7), 503-508. https://doi.org/10.1038/ngeo2186

Juul-Pedersen, T., Arendt, K. E., Mortensen, J., Blicher, M. E., Sogaard, D. H., \& Rysgaard, S. (2015). Seasonal and interannual phytoplankton production in a sub-Arctic tidewater outlet glacier fjord, SW Greenland. Marine Ecology Progress Series, 524, 27-38. https://doi. org/10.3354/meps11174

Kjeldsen, K. K., Mortensen, J., Bendtsen, J., Petersen, D., Lennert, K., \& Rysgaard, S. (2014). Ice-dammed lake drainage cools and raises surface salinities in a tidewater outlet glacier fjord, west Greenland. Journal of Geophysical Research: Earth Surface, 119, 1310-1321. https://doi.org/10.1002/2013JF003034

Large, W. G. (1998). Modeling and parameterization ocean planetary boundary layers. Ocean Modeling and Parameterization, 81-120. https://doi.org/10.1007/978-94-011-5096-5_3

Luo, H., Castelao, R. M., Rennermalm, A. K., Tedesco, M., Bracco, A., Yager, P. L., \& Mote, T. L. (2016). Oceanic transport of surface meltwater from the southern Greenland Ice Sheet. Nature Geoscience, 9(7), 528-532. https://doi.org/10.1038/ngeo2708 
Lydersen, C., Assmy, P., Falk-Petersen, S., Kohler, J., Kovacs, K. M., Reigstad, M., et al. (2014). The importance of tidewater glaciers for marine mammals and seabirds in Svalbard, Norway. Journal of Marine Systems, 129, 452-471. https://doi.org/10.1016/j. jmarsys.2013.09.006

Marchesiello, P., McWilliams, J. C., \& Shchepetkin, A. (2001). Open boundary conditions for long-term integration of regional oceanic models. Ocean Modelling, 3(1-2), 1-20. https://doi.org/10.1016/S1463-5003(00)00013-5

Marchesiello, P., McWilliams, J. C., \& Shchepetkin, A. (2003). Equilibrium structure and dynamics of the California Current System. Journal of Physical Oceanography, 33(4), 753-783. https://doi.org/10.1175/1520-0485(2003)33<753:ESADOT>2.0.CO;2

McGrath, D., Steffen, K., Overeem, I., Mernild, S. H., Hasholt, B., \& van den Broeke, M. (2010). Sediment plumes as a proxy for local ice-sheet runoff in Kangerlussuaq Fjord, West Greenland. Journal of Glaciology, 56(199), 813-821. https://doi.org/10.3189/002214310794457227

McSweeney, J. M., Chant, R. J., Wilkin, J. L., \& Sommerfield, C. K. (2017). Suspended-sediment impacts on light-limited productivity in the Delaware Estuary. Estuaries and Coasts, 40(4), 977-993. https://doi.org/10.1007/s12237-016-0200-3

Meire, L., Meire, P., Struyf, E., Krawczyk, D. W., Arendt, K. E., Yde, J. C., et al. (2016). High export of dissolved silica from the Greenland Ice Sheet. Geophysical Research Letters, 43(17), 9173-9182. https://doi.org/10.1002/2016GL070191

Meire, L., Mortensen, J., Meire, P., Sejr, M. K., Rysgaard, S., Nygaard, R., et al. (2017). Marine-terminating glaciers sustain high productivity in Greenland fjords. Global Change Biology, 23(12), 5344-5357. https://doi.org/10.1111/gcb.13801

Middelbo, A. B., Sejr, M. K., Arendt, K. E., \& Møller, E. F. (2018). Impact of glacial meltwater on spatiotemporal distribution of copepods and their grazing impact in Young Sound NE, Greenland. Limnology and Oceanography, 63(1), 322-336. https://doi.org/10.1002/ lno.10633

Millan, R., Rignot, E., Mouginot, J., Wood, M., Bjørk, A. A., \& Morlighem, M. (2018). Vulnerability of Southeast Greenland glaciers to warm Atlantic water from operation IceBridge and Ocean Melting Greenland data. Geophysical Research Letters, 45(6), 2688-2696. https://doi. org/10.1002/2017GL076561

Morlighem, M., Williams, C. N., Rignot, E., An, L., Arndt, J. E., Bamber, J. L., et al. (2017). BedMachine v3: Complete bed topography and ocean bathymetry mapping of Greenland from multibeam echo sounding combined with mass conservation. Geophysical Research Letters, 44, 11,051-11,061. https://doi.org/10.1002/2017GL074954

Morlighem, M., Wood, M., Seroussi, H., Choi, Y., \& Rignot, E. (2019). Modeling the response of northwest Greenland to enhanced ocean thermal forcing and subglacial discharge. The Cryosphere, 13(2), 723-734. https://doi.org/10.5194/tc-13-723-2019

Mortensen, J., Lennert, K., Bendtsen, J., \& Rysgaard, S. (2011). Heat sources for glacial melt in a sub-Arctic fjord (Godthåbsfjord) in contact with the Greenland Ice Sheet. Journal of Geophysical Research, 116, C01013. https://doi.org/10.1029/2010JC006528

Mouginot, J., Rignot, E., Bjørk, A. A., van den Broeke, M., Millan, R., Morlighem, M., et al. (2019). Forty-six years of Greenland Ice Sheet mass balance from 1972 to 2018. Proceedings of the National Academy of Sciences, 116(19), 9239-9244. https://doi.org/10.1073/ pnas. 1904242116

Münchow, A., Padman, L., \& Fricker, H. A. (2014). Interannual changes of the floating ice shelf of Petermann Gletscher, North Greenland, from 2000 to 2012. Journal of Glaciology, 60(221), 489-499. https://doi.org/10.3189/2014JoG13J135

Murray, C., Markager, S., Stedmon, C. A., Juul-Pedersen, T., Sejr, M. K., \& Bruhn, A. (2015). The influence of glacial melt water on bio-optical properties in two contrasting Greenlandic fjords. Estuarine, Coastal and Shelf Science, 163, 72-83. https://doi.org/10.1016/j. ecss.2015.05.041

Oliver, H., Luo, H., Castelao, R. M., van Dijken, G. L., Mattingly, K. S., Rosen, J. J., et al. (2018). Exploring the potential impact of Greenland meltwater on stratification, photosynthetically active radiation, and primary production in the Labrador Sea. Journal of Geophysical Research: Oceans, 123(4), 2570-2591. https://doi.org/10.1002/2018JC013802

Overeem, I., Hudson, B. D., Syvitski, J. P. M., Mikkelsen, A. B., Hasholt, B., Van Den Broeke, M. R., et al. (2017). Substantial export of suspended sediment to the global oceans from glacial erosion in Greenland. Nature Geoscience, 10(11), 859-863. https://doi.org/10.1038/ NGEO3046

Powell, T. M., Lewis, C. V. W. W., Curchitser, E. N., Haidvogel, D. B., Hermann, A. J., \& Dobbins, E. L. (2006). Results from a threedimensional, nested biological-physical model of the California Current System and comparisons with statistics from satellite imagery. Journal of Geophysical Research: Oceans, 111, C07018. https://doi.org/10.1029/2004JC002506

Schaffer, J., Kanzow, T., von Appen, W. J., von Albedyll, L., Arndt, J. E., \& Roberts, D. H. (2020). Bathymetry constrains ocean heat supply to Greenland's largest glacier tongue. Nature Geoscience, 13(3), 227-231. https://doi.org/10.1038/s41561-019-0529-x

Schwarz, J. N., \& Schodlok, M. P. (2009). Impact of drifting icebergs on surface phytoplankton biomass in the Southern Ocean: Ocean colour remote sensing and in situ iceberg tracking. Deep-Sea Research Part I: Oceanographic Research Papers, 56(10), 1727-1741. https:// doi.org/10.1016/j.dsr.2009.05.003

Sciascia, R., Straneo, F., Cenedese, C., \& Heimbach, P. (2013). Seasonal variability of submarine melt rate and circulation in an East Greenland fjord. Journal of Geophysical Research: Oceans, 118, 2492-2506. https://doi.org/10.1002/jgrc.20142

Sejr, M. K., Stedmon, C. A., Bendtsen, J., Abermann, J., Juul-Pedersen, T., Mortensen, J., \& Rysgaard, S. (2017). Evidence of local and regional freshening of Northeast Greenland coastal waters. Scientific Reports, 7(1), 13183. https://doi.org/10.1038/s41598-017-10610-9

Shepherd, A., Ivins, E. R., Geruo, A., Barletta, V. R., Bentley, M. J., Bettadpur, S., et al. (2012). A Reconciled Estimate of Ice-Sheet Mass Balance. Science, 338(6111), 1183-1189. https://doi.org/10.1126/science.1228102

Slater, D. A., Straneo, F., Felikson, D., Little, C. M., Goelzer, H., Fettweis, X., \& Holte, J. (2019). Estimating Greenland tidewater glacier retreat driven by submarine melting. The Cryosphere, 13(9), 2489-2509. https://doi.org/10.5194/tc-13-2489-2019

Straneo, F., \& Cenedese, C. (2015). The dynamics of Greenland's glacial fjords and their role in climate. Annual Review of Marine Science, 7(1), 89-112. https://doi.org/10.1146/annurev-marine-010213-135133

Straneo, F., Curry, R. G., Sutherland, D. A., Hamilton, G. S., Cenedese, C., Våge, K., \& Stearns, L. A. (2011). Impact of fjord dynamics and glacial runoff on the circulation near Helheim Glacier. Nature Geoscience, 4(5), 322-327. https://doi.org/10.1038/ngeo1109

Straneo, F., Hamilton, G., Stearns, L., \& Sutherland, D. (2016). Connecting the Greenland Ice Sheet and the ocean: A case study of Helheim Glacier and Sermilik Fjord. Oceanography, 29(4), 34-45. https://doi.org/10.5670/oceanog.2016.97

Straneo, F., Hamilton, G. S., Sutherland, D. A., Stearns, L. A., Davidson, F., Hammill, M. O., et al. (2010). Rapid circulation of warm subtropical waters in a major glacial fjord in East Greenland. Nature Geoscience, 3(3), 182-186. https://doi.org/10.1038/ngeo764

Straneo, F., Sutherland, D. A., Holland, D., Gladish, C., Hamilton, G. S., Johnson, H. L., et al. (2012). Characteristics of ocean waters reaching Greenland's glaciers. Annals of Glaciology, 53(60), 202-210. https://doi.org/10.3189/2012AoG60A059

Sutherland, D. A., Jackson, R. H., Kienholz, C., Amundson, J. M., Dryer, W. P., Duncan, D., et al. (2019). Direct observations of submarine melt and subsurface geometry at a tidewater glacier. Science, 365(6451), 369-374. https://doi.org/10.1126/science.aax3528

Sutherland, D. A., Straneo, F., \& Pickart, R. S. (2014). Characteristics and dynamics of two major Greenland glacial fjords. Journal of Geophysical Research: Oceans, 119, 3767-3791. https://doi.org/10.1002/2013JC009786 
Syvitski, J. P. M., Asprey, K. W., Clattenburg, D. A., \& Hodge, G. D. (1985). The prodelta environment of a fjord: Suspended particle dynamics. Sedimentology, 32(1), 83-107. https://doi.org/10.1111/j.1365-3091.1985.tb00494.x

Tagliabue, A., Aumont, O., DeAth, R., Dunne, J. P., Dutkiewicz, S., Galbraith, E., et al. (2016). How well do global ocean biogeochemistry models simulate dissolved iron distributions? Global Biogeochemical Cycles, 30, 149-174. https://doi.org/10.1002/2015GB005289. Received

Torsvik, T., Albretsen, J., Sundfjord, A., Kohler, J., Sandvik, A. D., Skarðhamar, J., et al. (2019). Impact of tidewater glacier retreat on the fjord system: Modeling present and future circulation in Kongsfjorden, Svalbard. Estuarine, Coastal and Shelf Science, 220(9296), 152-165. https://doi.org/10.1016/j.ecss.2019.02.005

Vernet, M., Sines, K., Chakos, D., Cefarelli, A. O., \& Ekern, L. (2011). Impacts on phytoplankton dynamics by free-drifting icebergs in the NW Weddell Sea. Deep-Sea Research Part II: Topical Studies in Oceanography, 58(11-12), 1422-1435. https://doi.org/10.1016/j. dsr2.2010.11.022

Wadham, J. L., Hawkings, J. R., Telling, J., Chandler, D., Alcock, J., O'Donnell, E., Kaur, P., Bagshaw, E. A., Tranter, M., Tedstone, A. J., Nienow, P., \& Lawson, E. (2016). Sources, cycling and export of nitrogen on the Greenland Ice Sheet. Biogeosciences Discussions, 13(22), 6339-6352. https://doi.org/10.5194/bg-2015-484

\section{References From the Supporting Information}

Brzezinski, M. A. (1985). The Si:C:N ration of marine diatoms: Interspecific variability and the effect of some environemental variables. Journal of Phycology, 21(3), 347-357.

Brzezinski, M. A., \& Nelson, D. M. (1989). Seasonal changes in the silicon cycle within a gulf stream warm-core ring. Deep Sea Research, 36(September), 35-37.

Fasham, M. J. R., Ducklow, H. W., \& McKelvie, S. M. (1990). A nitrogen-based model of plankton dynamics in the ocean mixed layer Journal of Marine Research, 48(3), 591-639. https://doi.org/10.1357/002224090784984678

Fennel, K., Wilkin, J., Levin, J., Moisan, J., O'Reilly, J., \& Haidvogel, D. (2006). Nitrogen cycling in the Middle Atlantic Bight: Results from a three-dimensional model and implications for the North Atlantic nitrogen budget. Global Biogeochemical Cycles, 20, GB3007. https:// doi.org/10.1029/2005GB002456

Joint, I. R., \& Pomroy, A. J. (1986). Photosynthetic characteristics of nanoplankton and picoplankton from the surface mixed layer. Marine Biology, 92(4), 465-474. https://doi.org/10.1007/BF00392506

Kishi, M. J., Kashiwai, M., Ware, D. M., Megrey, B. A., Eslinger, D. L., Werner, F. E., et al. (2007). NEMURO-a lower trophic level model for the North Pacific marine ecosystem. Ecological Modelling, 202(1-2), 12-25. https://doi.org/10.1016/j.ecolmodel.2006.08.021

Stuart, V., Sathyendranath, S., Head, E. J. H., Platt, T., Irwin, B., \& Maass, H. (2000). Bio-optical characteristics of diatom and prymnesiophyte populations in the Labrador Sea. Marine Ecology Progress Series, 201(1991), 91-106. https://doi.org/10.3354/meps201091

Twining, B. S., Nodder, S. D., King, A. L., Hutchins, D. A., LeCleir, G. R., DeBruyn, J. M., et al. (2014). Differential remineralization of major and trace elements in sinking diatoms. Limnology and Oceanography, 59(3), 689-704. https://doi.org/10.4319/lo.2014.59.3.0689 